\title{
SOSIAL EKONOMI DAN KONDISI KERJA PEREMPUAN PEDAGANG MAKANAN KAKI LIMA PADA MASA PANDEMI COVID-19 DI JAKARTA
}

\section{SOCIAL-ECONOMIC AND WORKING CONDITIONS OF WOMEN STREET FOOD VENDORS DURING THE PANDEMIC COVID-19 IN JAKARTA}

\author{
Dionisius Yusuf ${ }^{1}$, Christy Dwita Mariana ${ }^{2}$, Usman $^{3}$ \\ ${ }^{1,3}$ Institut Shanti Bhuana, Bengkayang, Kalimantan Barat \\ ${ }^{2}$ Universitas Agung Podomoro, Jakarta \\ Email: ${ }^{1}$ dionisius.yusuf@ shantibhuana.ac.id, ${ }^{2}$ Christy.mariana@ podomorouniversity.ac.id, \\ 3yohanes.usman@shantibhuana.ac.id
}

Dikirim 22 September 2021, Direvisi 12 Oktober 2021, Disetujui 29 November 2021

\begin{abstract}
Abstrak: Penelitian ini membahas isu-isu pedagang perempuan di sektor makanan kaki lima di Indonesia, khususnya Jakarta. Tulisan penelitian mencoba menggambarkan gambaran demografis dan kondisi kerja perempuan pedagang makanan jajanan kaki lima di kota Jakarta. Penelitian ini menggunakan sampel 100 wanita pedagang makanan kaki lima di kota Jakarta dengan berbagai metode dalam pengumpulan data. Kota Jakarta dipilih secara khusus karena jumlah perempuan pedagang makanan jajanan kaki lima yang meningkat pesat. Untuk memilih responden digunakan teknik purposive sampling. Observasi peneliti digunakan untuk mengumpulkan data. Data kuantitatif dianalisis menggunakan deskriptif, analisis Pearson dan Chi-square. Hasil penelitian menunjukkan di kalangan perempuan pedagang makanan kaki lima, kelompok usia 20 sampai 50 tahun merupakan kelompok yang dominan di Jakarta. Sebagian besar vendor berpendidikan rendah. Mayoritas vendors beretnis Jawa dan berasal dari Jawa Tengah dan Jawa Timur. Mayoritas pedagang telah berkeluarga dengan 2-3 anak. Selanjutnya kehidupan sehari-hari perempuan pedagang kaki lima pada masa pandemi Covid19 ditandai dengan kondisi kerja yang lebih buruk dibandingkan sebelum pandemi Covid-19 berlangsung, di mana $96 \%$ dari pedagang mengatakan pendapatannya menurun dari sebelum pandemi Covid-19. Penelitian juga menunjukkan rata-rata net income pedagang menurun lebih dari $30 \%$.
\end{abstract}

Kata kunci: Covid-19, Makanan Jajanan, Pandemi, Pendapatan, PKL, Wanita

Abstract: This study discusses the issues of women migrants in the street food sector in Indonesia, especially in Jakarta. This paper tries to describe the demographic and working conditions of migrant women street vendors in the city of Jakarta. This study used a sample of 100 women street vendors in the city of Jakarta with various methods of data collection. The cities were specifically selected due to rapidly increasing numbers of street food vendors. The selection of respondents used purposive sampling technique. The researcher's observations were used to collect data. Quantitative data were analyzed using percentages, bivariate analysis, Pearson analysis, and Chi-square. The results showed that among women street vendors, the age group of 20 to 50 years was the dominant group in Jakarta. Most of the vendors were poorly educated. The majority of the vendors are of Javanese ethnicity and come from Central Java and East Java. The majority of traders were married with 2-3 children. Furthermore, the daily life of women street vendors during the Covid-19 pandemic was marked by worse working conditions than before the Covid-19 pandemic, where $96 \%$ of the vendors said their income had decreased because of the Covid-19 pandemic. The research also shows that the average net income of women street food vendors has decreased by more than 30\% during the pandemic Covid-19.

Keywords: Covid-19, Income, Pandemic, Street Foods, Street Vendor, Women

\section{PENDAHULUAN}

Pedagang makanan kaki lima merupakan bagian integral dari sektor informal yang telah berkontribusi besar terhadap kegiatan perkotaan di banyak negara berkembang dan tampaknya menjadi salah satu kategori penting dari kegiatan ekonomi informal. Sebagai bagian dari sektor informal perkotaan, 
pedagang makanan jajanan kaki lima adalah salah satu kegiatan yang paling terlihat dalam perekonomian informal.

Pedagang makanan kaki lima (PMKL) adalah kegiatan yang dilakukan di luar ruangan seperti di jalan trotoar dan di tempat umum lainnya yang dilakukan secara permanen maupun temporal oleh para pedagang informal. Sifat dari pekerjaan tersebut biasanya menetap atau tidak bergerak dari satu tempat ke tempat lainnya. Pedagang kaki lima dianggap sebagai salah satu kegiatan informal yang dilakukan untuk oleh sebagian orang untuk bertahan hidup terutama di perkotaan (Yusuf dan Freytag-Leyer, 2019a) dan dikaitkan dengan orang-orang yang tidak memiliki keterampilan profesional dengan tingkat pendidikan rendah yang tidak dapat memperoleh pekerjaan di sektor formal.

Laporan dari negara-negara Asia Tenggara menunjukkan peningkatan jumlah PMKL setelah krisis keuangan tahun 1998 dan 2007, terutama di Indonesia dan Thailand. Pertumbuhan pedagang kaki lima juga menjadi fenomena di benua lain seperti Afrika dan Amerika Latin.

Bahkan menurut laporan dari FAO (2012), beberapa kota di Afrika, seperti Zimbabwe (Njaya, 2014); dan Tanzania (Marras, 2018), kaum perempuan mendominasi pekerjaan di sektor informal tersebut. Dominasi perempuan dalam pekerjaan informal PMKL juga terjadi di beberapa negara berkembang di Asia, seperti di Chonburi, Thailand (Gengaiah et al., 2018); Sarawak, Malaysia (Jores et al., 2018); Yangon, Myanmar (Lin dan Yamao, 2014), Hat Yai (Yusuf dan Freytag-Leyer, 2020) dan kota Ho Chi Minh, Vietnam (Thanh, 2015).

Pekerjaan di sektor informal seperti pedagang makanan kaki lima bagi perempuan merupakan pekerjaan yang sulit untuk dijalankan. Hal ini ditandai dengan hari kerja yang sangat panjang untuk pekerjaan tersebut. Sebagai contoh, di Phnom Penh, Kamboja, pedagang perempuan harus bekerja 8 - 13 jam sehari dan kebanyakan dari mereka harus menyeimbangkan jam kerja panjang mereka dengan tanggung jawab rumah tangga lainnya (ILO, 2016). Sebuah penelitian terhadap 294 responden memperlihatkan bahwa 68 persen pedagang perempuan di Maiduguri, Nigeria, melaporkan bahwa mereka bekerja rata-rata antara 8 hingga 11 jam sehari (WFP, 2017).

Kondisi serupa terjadi pada pedagang Nepal dimana perempuan PMKL harus bekerja selama 8 jam sehari untuk dapat menghasilkan uang untuk bertahan hidup buat keluarganya (Adhikari, 2017). Sebuah penelitian yang dilakukan di Dhaka, Bangladesh menemukan bahwa para wanita PKL yang menjual makanan yang dimasak mulai bekerja pagi-pagi untuk menyiapkan makanan, sehingga beberapa pedagang perempuan tersebut bekerja lebih lama (Habib, 2016).

Selanjutnya, perempuan PMKL di Tangerang dan Hat Yai bekerja lebih lama antara 8-14 jam sehari (Yusuf et al., 2020). Seperti yang dikatakan oleh banyak penulis, jam kerja PMKL pada umumnya tidak teratur. Sebagian besar dari mereka sering melebihi jam kerja standar yang ditetapkan pemerintah untuk pekerja formal dan menghabiskan lebih dari delapan jam per hari di pekerjaan tersebut. Alasan utama jam kerja yang panjang adalah ketidakpastian pendapatan dan keinginan untuk memperoleh penghasilan yang lebih banyak untuk membiayai kehidupan keluarga mereka.

Selain jam kerja, perempuan PMKL menghadapi bentuk kerentanan lain di tempat kerja. Perempuan PMKL dihadapkan pada ketidakamanan dan ketidakpastian karena vendor bekerja di pinggir jalan. Dalam sebuah survei, Yusuf dan Freytag-Leyer (2019b) menemukan bahwa karena tempat kerja para pedagang ini berada di ruang publik, seringkali tidak ada penyediaan fasilitas toilet yang dapat mengakibatkan kondisi kesehatan pedagang terganggu seperti mengalami penyakit diare. 
Selanjutnya Kumar dan Pillai (2017) menyatakan bahwa sebagian besar vendor tidak memiliki akses ke jaminan sosial atau tunjangan kesejahteraan seperti pensiun. Mereka mengungkapkan bahwa pemerintah daerah di lokasi studi mereka, Distrik Kollam, India tidak memberikan fasilitas kesehatan atau asuransi kepada para pedagang karena mereka termasuk dalam sektor informal yang tidak terorganisir. Karena PMKL tidak memiliki akses ke jaminan sosial yang dibantu pemerintah, Kumar (2015) melaporkan bahwa di Kerala, India, sekitar sepertiga pedagang meminjam uang untuk perlindungan sosial mereka termasuk perawatan kesehatan, obat-obatan, persalinan, dan kecelakaan. Yusuf et al. (2020) menyarankan bahwa pemerintah daerah harus terlibat dalam mengembangkan jaminan sosial bagi PMKL informal, terutama perawatan kesehatan, karena sebagian besar pedagang tinggal di lingkungan yang miskin dengan akses minimal atau tidak ada fasilitas lokal dan tidak mampu membeli layanan asuransi dari perusahaan swasta.

Selain waktu kerja yang relatif lama dan ketidakadaan jaminan sosial dan kesehatan bagi perempuan PMKL, pendapatan yang diperoleh oleh para pedagang pun tidak pasti. Terkadang mereka memperoleh pendapatan relatif besar, namun di lain waktu penghasilan mereka bisa menurun secara drastis. Tidak seperti sektor formal dimana pendapatan sesorang relatif stabil, tidak demikian yang dihadapi oleh para perempuan PMKL.

Pendapatan para pedagang semakin tidak menentu sejak pandemi Covid-19 melanda Indonesia. Penghasilan para pedagang yang tidak terlalu besar, semakin tergerus sejak terjadinya wabah Covid-19. Para PMKL merupakan salah satu kelompok masyarakat paling terdampak pandemi Covid-19. Penelitian dari Lembaga Pengembangan Ekonomi Bank Indonesia menunjukkan adanya penurunan omzet para pedagang hingga 50 persen.
Para perempuan PMKL yang terlibat dalam sektor informal merasakan kerugian akibat menurunnya pembeli sejak pandemi Covid-19. Nasib perempuan PMKL sangat menggenaskan karena daya beli masyarakat mengalami penurunan karena adanya pembatasan karyawan atau PHK, sehingga sebagian dari mereka mengalami penurunan pendapatan atau bahkan merugi. Selain itu, banyak para pedagang kehilangan mata pencaharian. Penutupan lokasi jualan atau sepinya pembeli juga menjadi sebab banyak pedagang terpaksa harus berhenti berjualan.

Tulisan ini bertujuan untuk secara khusus mengeksplorasi kondisi kerja dan sosial ekonomi perempuan pedagang makanan jajanan kaki lima selama pandemi Covid-19 berlangsung di Indonesia, khususnya di kota Jakarta. Kajian ini menjadi sangat penting, karena sebagian besar perempuan pedagang makanan jajanan kaki lima adalah salah satu pihak yang paling terdampak akibat pandemi Covid-19 dimana sebagian dari mereka mengalami kondisi kerja yang semakin tidak baik akibat adanya pandemi ini.

\section{LANDASAN TEORI}

\section{A. Pedagang Makanan Kaki Lima sebagai Sektor Unggulan Ekonomi Informal}

Menurut FAO makanan jajanan didefinisikan sebagai makanan dan minuman siap saji yang disiapkan dan/atau dijual oleh penjaja atau penjaja, terutama di jalan dan tempat umum lain yang dapat langsung dimakan tanpa pengolahan atau persiapan lebih lanjut. Sedangkan WHO mendefinisikan makanan kaki lima sebagai makanan dan minuman yang disiapkan dan dijual oleh pedagang kaki lima di jalanjalan dan tempat-tempat umum lainnya untuk segera dikonsumsi tanpa pengolahan atau persiapan lebih lanjut. Lokasi vendor biasanya merupakan tempat-tempat populer seperti pasar, sudut jalan yang ramai dan lokasi yang strategis. 
Setidaknya ada tiga ciri utama perdagangan jajanan kaki lima. Pertama, makanan kaki lima merupakan aktivitas kewirausahaan dan sumber pendapatan yang penting bagi kaum miskin perkotaan dan pedesaan, khususnya perempuan yang seringkali menjadi korban pertama kemiskinan (Tinker, 2003). Kedua, makanan kaki lima adalah bisnis dengan harga terjangkau, rasa dan mudah didapat (Yusuf et al., 2013). Ketiga, makanan kaki lima merupakan salah satu pilihan nutrisi bagi masyarakat miskin perkotaan yang seringkali hanya mampu membeli makanan dalam jumlah kecil (Bhat, 2000).

Sebagai sarana untuk menyediakan sumber pendapatan dan lapangan kerja bagi masyarakat miskin perkotaan, sektor makanan jajanan merupakan cara sederhana untuk menghasilkan pendapatan untuk memenuhi kebutuhan keluarga (Adhikari, 2017). Banyak pekerja migran dan pengangguran yang sedang mencari pekerjaan memperoleh penghasilan pertama dari usaha jajanan kaki lima. FAO (2012) menunjukkan bahwa perempuan adalah salah satu pelaku usaha dominan dalam bisnis ini yang memberikan kontribusi yang signifikan terhadap perekonomian suatu negara.

\section{B. Karakteristik Sektor Makanan Kaki Lima}

Istilah 'makanan kaki lima' yang digunakan dalam penelitian ini mengacu pada makanan yang disiapkan di jalan atau disiapkan di rumah dan untuk dijual kepada publik di jalan - artinya di trotoar (termasuk jalan pejalan kaki) tanpa memiliki bangunan permanen tetapi dengan struktur statis sementara atau kios bergerak (atau beban kepala). Pedagang kaki lima dapat diam dengan menempati ruang di jalan, trotoar atau tempat umum/pribadi lainnya atau mungkin berpindah-pindah dalam arti berpindah dari satu tempat ke tempat lain dengan membawa barang dagangannya di gerobak dorong atau di atas sepeda atau keranjang di atas kepala mereka untuk dijual. makanan mereka.

Studi Fixy (2004) tentang pedagang jajanan makanan kaki lima di kawasan khusus Jakarta menunjukkan bahwa perempuan juga berperan aktif dalam bisnis makanan kaki lima. Perempuan menjalankan bisnis tersebut dalam rangka membantu keuangan keluarga dan bahkan ada yang menjadi sumber pendapatan utama keluarga. Sebagian besar peneliti mengatakan bahwa salah satu karakteristik bisnis makanan kaki lima adalah biasanya dimiliki dan dioperasikan oleh individu atau keluarga. Nirathron (2006) menemukan bahwa dari 744 pedagang kaki lima di Bangkok, sekitar 37,0\% diantaranya dijalankan secara individu, sementara 44,0\% lainnya dioperasikan oleh keluarga.

\section{Kondisi Kerja Dalam Sektor Makanan Kaki Lima}

Hampir di seluruh dunia, pekerjaan para PMKL ditandai dengan hari kerja yang sangat panjang. Di Phnom Penh, Kamboja, pedagang perempuan bekerja selama 8-13 jam per hari dan kebanyakan dari mereka harus menyeimbangkan jam kerja panjang mereka dengan tanggung jawab rumah tangga lainnya (ILO, 2016). Sebuah penelitian terhadap 296 responden di Hat Yai dan Tangerang memperlihatkan bahwa pedagang bekerja rata-rata antara 8 hingga 14 jam sehari (Yusuf et al., 2020). Sedangkan di Nepal, para perempuan MPKL makanan harus bekerja 8,8 jam untuk mendapatkan penghasilan yang memungkinkan mereka menyediakan penghidupan bagi keluarga mereka (Adhikari, 2017).

Sebuah penelitian yang dilakukan di Dhaka, Bangladesh menemukan bahwa para wanita pedagang PMKL yang menjual makanan yang dimasak mulai bekerja pagi hari untuk menyiapkan makanan, sehingga beberapa pedagang harus bekerja lebih lama dari biasanya. Seperti yang dikatakan oleh banyak peneliti, jam kerja PMKL pada umumnya 
tidak biasa dan tidak teratur. Sebagian besar dari mereka sering bekerja melebihi jam kerja standar yang ditetapkan pemerintah untuk pekerja formal dan menghabiskan lebih dari delapan jam per hari. Alasan utama jam kerja yang panjang adalah ketidakpastian pendapatan.

Selain jam kerja, perempuan pedagang kaki lima menghadapi bentuk kerentanan lain di tempat kerja. Dalam menjalankan bisnis para perempuan PMKL menghadapi ketidakamanan dan ketidakpastian karena mereka bekerja di pinggir jalan dan kecelakaan dapat terjadi kapan saja. Kajian dari FAO (2012) menunjukkan bahwa secara umum pekerja di sektor informal bidang pangan sering kali memiliki keterbatasan akses terhadap layanan dasar, termasuk akses terhadap air minum. Oleh karena itu, para pedagang, khususnya perempuan yang tidak memiliki akses terhadap layanan dasar dapat menghadapi masalah kebersihan dan keamanan makanan. Misalnya, kualitas gizi makanan jalanan yang dijual kepada konsumen dipertanyakan keamanan pangannya.

Terkait dengan jaminan sosial sebagian besar vendor di tempat kerja mengatakan bahwa mereka tidak memiliki akses ke jaminan sosial atau tunjangan kesejahteraan seperti pensiun. Mereka mengungkapkan bahwa pemerintah daerah tidak memberikan layanan kesehatan atau asuransi kepada para pedagang karena mereka termasuk dalam sektor informal yang tidak terorganisir (Kumar dan Pillai (2017).

Karena pedagang kaki lima tidak memiliki akses ke jaminan sosial yang dibantu oleh pemerintah, maka sekitar sepertiga pedagang meminjam uang untuk perlindungan sosial mereka termasuk perawatan kesehatan, obat-obatan, persalinan, dan kecelakaan. Lund (2009) menyarankan bahwa pemerintah daerah harus terlibat dalam mengembangkan jaminan sosial bagi pedagang kaki lima informal, terutama perawatan kesehatan, karena sebagian besar pedagang tinggal di lingkungan yang miskin dengan akses minimal atau tidak ada fasilitas lokal dan tidak mampu membeli layanan asuransi dari perusahaan swasta. Lebih lanjut Lund mengungkapkan bahwa pemerintah baik lokal maupun pusat bersama-sama dengan lembaga lainnya harus membantu memberikan jaminan sosial dan keamanan kepada para pedagang makanan kaki lima khususnya kaum perempuan.

\section{Kondisi Sosial Ekonomi Wanita Pedagang Makanan Kaki Lima}

Sektor makanan kaki lima merupakan sumber makanan yang penting bagi masyarakat urban dan memberikan pendapatan bagi para penjualnya terutama perempuan di berbagai belahan dunia. Sebagian besar pedagang kaki lima tertarik pada pekerjaan ini karena kemungkinan mendapatkan penghasilan yang relatif tinggi. Yusuf dan Freytag-Leyer (2020) melaporkan bahwa PKL di Hat Yai dan Tangerang memperoleh upah lebih dari upah minimum di daerah tersebut. Di beberapa negara, pedagang kaki lima dapat memperoleh penghasilan jauh di atas upah minimum. Di Kota Maseru, Lesotho, Gadaga dkk. (2014) melaporkan bahwa hampir semua vendor memperoleh keuntungan hampir lima kali lipat dari penghasilan pekerja di pabrik tekstil, yaitu sekitar sepuluh kali upah minimum. Darko-Koomson (2016) menunjukkan bahwa pendapatan penjualan rata-rata yang dihasilkan oleh pemilik penjual makanan kaki lima sekitar sembilan kali lebih besar dari upah minimum harian nasional di Ghana. Demikian pula di Kumasi, Ghana keuntungan yang diperoleh PKL hampir 16 kali lebih tinggi dari upah minimum nasional untuk pedagang kaki lima. Sedangkan di Accra, Ghana PKL memiliki pendapatan sedikit lebih tinggi daripada upah minimum resmi yang diperoleh pekerja sektor publik.

Seperti pedagang di kota-kota Afrika, perempuan PMKL di Asia juga memperoleh penghasilan di atas rata-rata upah minimum regional. Pendapatan ratarata seorang pedagang bisa tiga sampai 
sepuluh kali lipat dari upah minimum dan seringkali sebanding dengan upah pekerja terampil yang dipekerjakan di sektor formal. Etzold dkk. (2013) menunjukkan bahwa di Dhaka, Bangladesh pendapatan perempuan PMKL merupakan pendapatan yang cukup besar dibandingkan dengan upah pekerja pabrik atau buruh harian. Di Bangkok, Thailand, Kusakabe (2006) mempublikasikan bahwa pendapatan dari perempuan PMKL relatif tinggi dibandingkan dengan upah minimum Bangkok. Sejalan dengan laporan tersebut, pendapatan harian sebagian besar pedagang kaki lima di Jakarta berkisar antara Rp 300.000 hingga Rp 1.000.000 (Fixy, 2004). Pendapatan tersebut melebihi standar upah minimum yang ditetapkan oleh Pemerintah Jakarta. Pendapatan harian yang lebih tinggi dibandingkan dengan pekerja formal mungkin menjadi salah satu alasan mengapa orang bertahan dalam bisnis ini selama beberapa tahun. Namun, tingkat pendapatan PMKL sangat terkait dengan berbagai hal, antara lain jenis barang yang dijual dan lokasi penjualan.

Pandemi Covid-19 telah mempengaruhi pendapatan pekerja informal terutama di kota besar. Sebelum pandemi melanda, pendapatan pekerja informal seperti PMKL terbilang cukup untuk menghidupi keluarga mereka. Namun setahun terakhir, karena bisnis dan kantor di beberapa kota di Indonesia ditutup karena adanya virus Corona, maka pendapatan para PMKL pun menurun secara drastis. Bahkan banyak PMKL yang menghentikan aktivitas bisnisnya selama masa pandemi ini. Seakan-akan wadah Corona menjadi lonceng kematian bagi sebagian pelaku usaha PMKL.

Penelitian yang dilakukan terhadap para PMKL di Pasar Tradisional Padang Bulan, Medan memperlihatkan bahwa para pedagang buah dan sayur tetap bertahan melakukan usahanya di pasar walaupun dalam masa pandemi dan jumlah pembeli serta pendapatan yang menurun hingga lebih dari 50\% (Sinaga dan Purba, 2020).
Hasil penelitian lainnya yang dilakukan oleh Hariyani (2021) terhadap Pedagang makanan kaki lima yang ada di Lapangan Desa Karangrejo, kediri menunjukkan bahwa akibat pandemi Covid-19 para PMKL mengalami penurunan pendapatan drastis, namun mereka berhasil bangkit dan mempertahankan usahanya meski pendapatan mereka tidak bisa kembali seperti semula.

Pendapatan para PKL tampaknya agak susah untuk kembali normal dalam waktu dekat. Pemberlakuan pembatasan kegiatan masyarakat atau PPKM di berbagai wilayah di Indonesia termasuk di kota Jakarta yang berlangsung sejak 12 Juli 2021 dan terus diperpanjang telah berdampak pada pedagang kaki lima di kota tersebut. Hasil penelitian dan laporan dari Asosiasi Pedagang Kaki Lima Indonesia (APKLI), para PKL semakin terpuruk karena mengalami penurunan omzet yang sangat drastis yaitu berkisar hingga 80 persen. Dampak pandemi Covid-19 sangat luar biasa terhadap pedagang kecil seperti PKL. Meskipun mendapatkan pendapatan yang sedikit, sebagian dari para PKL makanan tetap melakukan aktivitas bisnisnya agar tetap bisa bertahan hidup daripada tidak ada pemasukan sama sekali. Untuk kembali meningkatkan pendapatan dan kesejahteraan para pedagang, maka program pemberdayaan dan pelatihan pada masyarakat perlu digalakkan melalui program-program yang diselenggarakan oleh pemerintah daerah (Beni et al., 2021).

\section{METODOLOGI}

Penelitian ini dilakukan di kota Jakarta. Jakarta sampai hari ini telah menjadi pelabuhan bagi sejumlah besar migran dari berbagai daerah di tanah air. Selain itu, kota Jakarta dipilih secara khusus sebagai lokasi penelitian karena jumlah pedagang kaki lima yang meningkat pesat. Di Jakarta penelitian dilakukan di 5 kotamadya yang ada di Jakarta, yaitu Jakarta Pusat, Jakarta Utara, Jakarta Selatan, Jakarta Timur dan Jakarta Selatan. 
Jenis data yang digunakan dalam penelitian ini adalah data primer dan sekunder. Variabel yang digunakan dalam penelitian ini adalah variabel terikat dan variabel bebas. Variabel bebas terdiri dari jumlah pekerja yang dibayar, transportasi yang digunakan untuk mengangkut produk ke tempat perdagangan, dan rata-rata jam kerja. Sedangkan variabel terikat dalam penelitian ini adalah kondisi kerja wanita pedagang kaki lima.

Teknik purposive sampling digunakan untuk memilih perempuan pedagang kaki lima sebagai responden di Jakarta. Untuk penelitian ini, jumlah sampel yang dikumpulkan berjumlah 100 responden yang terdiri dari 20 responden di setiap kotamadya yang diteliti.

Pemilihan responden harus memenuhi kriteria sebagai berikut: 1). Pedagang kaki lima harus menjajakan makanan siap saji di jalan atau di tempat umum dengan sepeda, gerobak makanan, warung makan maupun di kios; 2). Responden harus pemilik usaha jajanan kaki lima, bukan pegawai; dan 3). Sebelum memulai dengan kuesioner, pertanyaan pertama adalah tentang tempat kelahiran calon responden, untuk mengidentifikasi dia sebagai migran. Selanjutnya, ambang enam bulan durasi bisnis ditetapkan untuk meningkatkan validitas tanggapan.

Data kuantitatif hasil penelitian dianalisis menggunakan SPSS versi 25.0. Selanjutnya teknik deskriptif seperti distribusi frekuensi, persentase, rentang, mean, median, standar deviasi, dan tabulasi silang digunakan untuk menggambarkan kondisi kerja wanita pedagang kaki lima. Sedangkan teknik analisis statistik yang digunakan dalam penelitian ini adalah uji Chi-Square, Cramel's V dan Korelasi Pearson. Kedua uji ini dilakukan untuk menyelidiki hubungan antara dua variabel yang diuji.

\section{HASIL DAN PEMBAHASAN}

\section{A. Demografi responden}

Hasil penelitian seperti yang terlihat pada Tabel 1, penjual jajanan kaki lima adalah kegiatan yang dilakukan oleh berbagai kelompok usia dengan konsentrasi penjual berada pada berusia antara 21 - 40 tahun yaitu 62 persen. Ratarata usia pedagang di Jakarta adalah 36,4 tahun dengan standar deviasi 9,8 tahun, Temuan ini menunjukkan bahwa pedagang kaki lima informal merupakan sumber pekerjaan bagi penduduk aktif yang bekerja yang tidak mengambil bagian dalam pasar kerja formal.

Tabel 1. Kelompok Usia Responden

\begin{tabular}{|c|c|}
\hline Kelompok Usia & Persentase \\
\hline$<20$ tahun & 2 \\
\hline $20-25$ tahun & 12 \\
\hline $26-30$ tahun & 22 \\
\hline $31-35$ tahun & 18 \\
\hline $36-40$ tahun & 8 \\
\hline $41-45$ tahun & 18 \\
\hline $46-50$ tahun & 12 \\
\hline$>50$ tahun & 8 \\
\hline
\end{tabular}

Sumber: Data Primer (2021)

Hasil penelitian menunjukkan sebagian besar responden (80 persen) telah menikah. Sedangkan 10 persen menyatakan mereka masih single. Sisanya mempunyai status bercerai dengan pasangannya. Perbedaan status perkawinan dengan usia signifikan secara statistik $(\mathrm{p}<0,01)$ dimana pedagang berusia dibawah 25 tahun cenderung masih hidup sendiri dan belum berkeluarga. Sedangkan pedagang yang berusia diatas 25 tahun cenderung sudah berkeluarga. 
Tabel 2. Jumlah Anak Responden

\begin{tabular}{|c|c|}
\hline Jumlah Anak & Persentase \\
\hline 0 & 24.0 \\
\hline 1 & 22.0 \\
\hline 2 & 32.0 \\
\hline 3 & 18.0 \\
\hline 4 & 4.0 \\
\hline
\end{tabular}

Sumber: Data Primer (2021)

Rata-rata jumlah anggota keluarga wanita pedagang di Jakarta adalah 3,08 dengan standar deviasi 1,46. Hal ini menunjukkan bahwa selain diri mereka sendiri, sebagian besar pedagang bertanggung jawab atas setidaknya satu anggota keluarga. Banyak pedagang kaki lima yang tidak hanya memberikan penghasilan bagi diri mereka sendiri tetapi juga bertanggung jawab atas kelangsungan hidup keluarga besar mereka, seperti orang tua, saudara dan sepupu mereka. Hasil penelitian pada Tabel 2 diatas juga menunjukkan bahwa 32 persen dari total responden memiliki dua orang anak, sedangkan hanya 4 persen dari total responden yang memiliki anak lebih dari tiga.

Dari segi distribusi etnis, mayoritas pedagang kaki lima di Jakarta seperti yang terlihat pada Tabel 3 adalah Jawa (44\%), diikuti oleh Sunda (34\%) dan Betawi $(8 \%)$. Penyebaran etnis tersebut tidak terlepas dari daerah asal para pedagang. Hasil penelitian memperlihatkan bahwa sebagian pedagang berasal dari Jawa Tengah (32\%), diikuti Jawa Barat (28\%) dan Jawa Timur (14\%).

Tabel 3. Etnis Responden

\begin{tabular}{|c|c|}
\hline Etnis & Persentase \\
\hline Sunda & 34.0 \\
\hline Jawa & 44.0 \\
\hline Tionghoa & 2.0 \\
\hline Batak & 2.0 \\
\hline Betawi & 8.0 \\
\hline Madura & 4.0 \\
\hline Padang & 2.0 \\
\hline
\end{tabular}

\begin{tabular}{|l|r|} 
Lainnya & 4.0 \\
\hline
\end{tabular}

Sumber: Data Primer (2021)

Afiliasi agama pedagang yang diperoleh dari penelitian lapangan menunjukkan bahwa mayoritas pedagang beragama Islam (85 persen) ini diikuti oleh Kristen Protestan dan Katolik masing-masing sebesar $8 \%$ dan $4 \%$. Hanya $2 \%$ dan $1 \%$ pedagang kaki lima yang menganut agama Budha dan Hindu. Hal ini menggambarkan bahwa data yang ditampilkan mengenai agama yang dianut pedagang kaki lima dalam penelitian ini hampir sama dengan proporsinya di kota Jakarta.

Hasil penelitian di Jakarta seperti ditunjukkan pada Tabel 4 memperlihatkan bahwa tingkat pendidikan para pedagang tergolong rendah. Sebagian besar responden (38 persen) dilaporkan berpendidikan sekolah menengah atau SMP. Sebaliknya, hanya 4 persen responden yang mengenyam pendidikan di perguruan tinggi. Temuan ini didukung oleh pola dan tren gender terkini di Indonesia dimana dari data yang dikumpulkan UNFPA Indonesia tahun 2010 (2015), sebagian besar PKL di Indonesia berpendidikan rendah.

Tabel 4. Tingkat Pendidikan Responden

\begin{tabular}{|c|c|}
\hline Tingkat Pendidikan & Persentase \\
\hline SMP & 38.0 \\
\hline SMA & 32.0 \\
\hline Diploma & 26.0 \\
\hline Sarjana & 4.0 \\
\hline
\end{tabular}

Sumber: Data Primer (2021)

Secara statistik terdapat perbedaan tingkat pendidikan yang signifikan antara kelompok umur responden dengan menggunakan uji Chi-square, 2, dan Cramer's V $\quad(p<0,01)$. Perbedaan ini kemungkinan besar karena kelompok usia muda telah mengenyam pendidikan lebih tinggi daripada kelompok usia lebih tua. Anak muda atau milenial lebih sadar akan pentingnya pendidikan dibandingkan generasi sebelumnya. 


\section{B. Kondisi Kerja Perempuan Migran PKL Makanan Sebelum dan Ketika Pandemi Covid-19}

Hari perempuan PKL makanan adalah hari yang panjang. Sebagian dari mereka sudah memulai aktivitas sejak pukul 4 pagi hari. Sebelum beraktivitas, mereka harus menyelesaikan semua pekerjaan rumah tangga, menyiapkan sarapan dan kemudian mengunjungi pasar untuk membeli barang. Sebagian pedagang yang terlibat menjual makanan sarapan harus mencapai kios mereka pada pukul 6 pagi. Para pedagang ini bekerja selama lima jam di warung, pulang ke rumah untuk menyiapkan makan siang untuk keluarga mereka, membersihkan rumah, menyegarkan diri dan istirahat sejenak.

Mayoritas pedagang yang menjual makanan buat makan malam akan memulai aktivitasnya dari pukul 4 sore hingga 12 malam bahkan ada yang berakhir hingga pukul 2 dini hari. Selain itu, sebagian responden mengatakan tidak ada akhir pekan dan hari libur di benak mereka. Oleh karena itu, untuk memastikan pendapatan mereka, para pedagang kaki lima memanfaatkan setiap kesempatan untuk dapat mendirikan warung dan bekerja berjam-jam tanpa istirahat.

Moda perjalanan antara tempat tinggal dan tempat kerja sangat berbeda antara satu pedagang dengan pedagang lainnya. Seperti yang terlihat pada Tabel 5, sebagian besar vendor, di Jakarta (50 persen) bepergian menggunakan sepeda motor sendiri ke tempat kerja mereka. Lebih dari 20,0 persen vendor di Tangerang berjalan kaki ke tempat kerja mereka dan hanya 4\% menggunakan mobil mereka sendiri untuk mencapai tempat kerja mereka. Sebagian besar vendor menyatakan bahwa mereka lebih suka berjualan tidak jauh dari tempat tinggal mereka dalam rangka mengurangi biaya transportasi dan memudahkan mobilitas ketika berjualan.
Tabel 5. Moda Transportasi Responden

\begin{tabular}{|c|c|}
\hline Moda Transportasi & Persentase \\
\hline Kendaraan umum & 15 \\
\hline Motor & 50 \\
\hline Mobil & 4 \\
\hline Berjalan kaki & 20 \\
\hline Lainnya & 11 \\
\hline
\end{tabular}

Sumber: Data Primer (2021)

Selama penelitian, sebagian besar pedagang di Jakarta mengatakan bahwa perjalanan mereka memakan waktu sekitar 30 menit atau lebih ke tempat kerja mereka. Oleh karena itu, mereka lebih suka menggunakan sepeda motor sendiri karena memungkinkan mereka lebih mandiri dan fleksibel. Selain itu bepergian dengan sepeda motor lebih murah daripada angkutan umum. Para pedagang kaki lima lebih banyak menggunakan sepeda motor untuk perjalanan jarak jauh. Dalam konteks ini, sepeda motor merupakan solusi mobilitas sehari-hari yang mudah bagi para pedagang karena jauh lebih murah untuk digunakan daripada taksi atau memiliki mobil dan juga jauh lebih cepat daripada berjalan kaki.

Penelitian juga menunjukkan bahwa banyak vendor tinggal tidak jauh dari tempat kerja mereka (di bawah sepuluh menit). Akibatnya, mereka memilih untuk mencapai tempat kerja mereka dengan berjalan kaki. Angkot dan ojek merupakan angkutan umum yang biasa digunakan oleh para pedagang kaki lima di Jakarta. Ini adalah moda transportasi umum yang lebih disukai karena dua alasan - pertama, untuk pedagang yang tidak bisa mengendarai sepeda motor atau mengendarai mobil dan kedua, untuk pedagang yang merasa lebih nyaman dan lebih aman di angkutan umum daripada mengemudi sendiri. Sangat sedikit orang yang dilaporkan bepergian dengan mobil mereka sendiri atau membawa peralatan mereka. Responden menyebutkan bahwa keamanan tidak menjadi perhatian saat mengangkut makanan untuk bisnis mereka. 
Hasil penelitian memperlihatkan bahwa para perempuan PKL makanan belum tergerak untuk berpartisipasi dalam skema jaminan sosial meskipun mereka mengetahui manfaat dari skema tersebut. Alasan utamanya adalah banyak dari mereka tidak memiliki kontrak kerja tetap dan tanpa jumlah gaji yang tetap, yang membuat partisipasi mereka bermasalah. Meskipun pemerintah mungkin dapat membantu para pedagang tersebut dalam tahap pendaftaran, keanggotaan jangka panjang mereka masih belum pasti. Seperti kebanyakan pekerja informal, sebagian besar pedagang makanan yang diwawancarai menyatakan bahwa mereka tidak memiliki jaminan sosial atau tunjangan kesejahteraan seperti pensiun, asuransi kecelakaan kerja, atau tunjangan asuransi jiwa.

Perlindungan kesehatan tidak dapat disangkal penting bagi setiap warga negara, terutama bagi pekerja informal, karena profesi mereka penuh dengan ketidakpastian dan ketidakpastian. Karena lokasi tempat kerja mereka di tempattempat ramai, di trotoar atau di pinggir jalan, kecelakaan kemungkinan besar terjadi kapan saja. Selain itu, sebagian perempuan mungkin terpapar kesehatannya karena kebersihan yang buruk dan kondisi cuaca buruk, sehingga pedagang cenderung lebih mudah jatuh sakit daripada warga lainnya. Ketika pedagang atau anggota keluarga mereka jatuh sakit, produktivitas mereka sangat terpengaruh, yang mengakibatkan hilangnya pendapatan dan kemungkinan jatuh ke dalam kemiskinan. Oleh karena itu, bantuan untuk memenuhi biaya perawatan kesehatan diperlukan di seluruh masyarakat, terutama bagi masyarakat miskin dan rentan.

Sektor informal seperti PKL adalah usaha yang sebagian besar merupakan pengusaha mikro, yang menyediakan lapangan kerja tidak hanya untuk diri mereka sendiri tetapi juga untuk orang lain yang menganggur. Sebelum adanya pandemi Covid-19, 10 persen vendor di
Jakarta mempekerjakan pekerja berbayar untuk bekerja dengan mereka. Namun dengan adanya pandemi Covid-19, persentase perempuan PKL makanan yang mempekerjakan tenaga bantuan berkurang menjadi hanya 4 persen. Hal ini memperlihatkan bahwa pandemi Covid-19 telah membawa dampak yang sangat signifikan terhadap penyerapan jumlah tenaga kerja di sektor informal. Para pedagang mengatakan mereka tidak lagi memperkerjakan karyawan karena bisnis yang digeluti sedang lesu sehingga mereka tidak mampu membayar gaji karyawan.

Wabah Covid-19 yang sudah berlangsung lebih dari satu tahun turut membawa pengaruh terhadap partisipasi keluarga dalam bisnis ini. Hasil penelitian seperti yang ditunjukkan pada Tabel 6 memperlihatkan bahwa sebelum pandemi Covid-19, persentase anggota keluarga yang membantu dalam bisnis adalah 62 persen. Persentase ini terus meningkat sejak adanya pandemi Covid-19. Ketika penelitian ini dilakukan, para responden menyatakan bahwa ada peningkatan partisipasi dari anggota keluarga terhadap bisnis yang mereka geluti. Meskipun peningkatannya tidak terlalu signifikan, namun hal ini menunjukkan bahwa para anggota keluarga mulai melirik bisnis yang dijalankan oleh orang tua, saudara atau istri mereka sebagai sarana untuk mencari penghasilan. Alasan lainnya adalah terjadinya pengurangan penggunaan karyawan berbayar oleh pedagang. Hal ini mengakibatkan anggota keluarga harus menggantikan posisi karyawan yang tidak lagi bekerja pada pedagang tersebut.

Tabel 6. Partisipasi Anggota Keluarga

\begin{tabular}{|l|r|r|}
\hline \multirow{2}{*}{} & \multicolumn{2}{|c|}{ Persentase } \\
\cline { 2 - 3 } & \multicolumn{1}{|c|}{ Ya } & \multicolumn{1}{c|}{ Tidak } \\
\hline Sebelum Covid & 62 & 38 \\
\hline Ketika Covid & 66 & 34 \\
\hline
\end{tabular}

Sumber: Data Primer (2021)

Dalam sektor informal seperti PKL makanan, tidak jarang perempuan menjadi 
pencari nafkah utama dalam keluarga, bahkan menjadi pencari nafkah tunggal buat keluarganya. Hasil penelitian menunjukkan bahwa dari total responden, 30 persen dari total responden menyatakan bahwa pasangan atau suami mereka tidak bekerja yang mengakibatkan mereka harus bekerja sebagai pencari nafkah utama buat keluarga.

Berdasarkan hasil wawancara, di antara para suami yang memiliki pekerjaan, sebagian besar bekerja di sektor informal dengan pendapatan yang tidak menentu, sehingga upah yang diperoleh tidak dapat menopang kehidupan keluarga. Para responden menyatakan bahwa sebagian besar dari pasangan mereka bekerja sebagai buruh harian lepas seperti buruh bangunan, satpam, pedagang kecil dan kegiatan lainnya. Ketidakpastiaan upah dari pasangan menjadi salah satu penyebab para perempuan terjun ke bisnis makanan jalanan dan memikul tanggungjawab untuk memenuhi kebutuhan keluarga.

\section{Kondisi Sosial Ekonomi Perempuan Migran PKL Makanan Sebelum dan Ketika Pandemi Covid-19}

Sulit untuk mendapatkan informasi mengenai pendapatan pedagang makanan jalanan secara akurat. Penghasilan para pedagang bervariasi dari hari ke hari dan dari bulan ke bulan. Selain itu, pendapatan pedagang kaki lima tergantung pada berbagai faktor seperti jenis barang dagangan yang dijual, tempat mereka beroperasi, volume perdagangan dan syarat perdagangan. Namun, sebagian besar responden mau memberikan informasi yang tepat tentang rata-rata pendapatan dan pendapatan bersih per hari yang mereka peroleh dari bisnis mereka.

Tabel 7. Tingkat Pendapatan Per Hari

\begin{tabular}{|l|c|c|}
\hline & $\begin{array}{c}\text { Mean } \\
(\mathrm{Rp})\end{array}$ & $\begin{array}{c}\text { Std. } \\
\text { Deviation } \\
(\mathrm{Rp})\end{array}$ \\
\hline $\begin{array}{l}\text { Omzet sebelum } \\
\text { Covid }\end{array}$ & 1.336 .000 & 1.192 .581 \\
\hline
\end{tabular}

\begin{tabular}{|l|c|c|}
$\begin{array}{l}\text { Net omzet } \\
\text { sebelum Covid }\end{array}$ & 879.000 & 1.088 .488 \\
\hline $\begin{array}{l}\text { Omzet ketika } \\
\text { Covid }\end{array}$ & 935.200 & 1.119 .419 \\
\hline $\begin{array}{l}\text { Net omzet } \\
\text { ketika Covid }\end{array}$ & 609.700 & 1.005 .358 \\
\hline
\end{tabular}

Sumber: Data Primer (2021)

Dari hasil penelitian seperti tersaji pada Tabel 7 terlihat bahwa rata-rata pendapatan harian pedagang kaki lima di Jakarta sebelum Covid-19 terjadi di Indonesia adalah sebesar Rp 1.336.000,00 dengan standar deviasi sebesar $\mathrm{Rp}$ 1.192.581,00. Namun pendapatan harian pada pedagang makanan jajanan tersebut menurun drastis ketika Covid-19 melanda Indonesia. Tabel 7 juga memperlihatkan pendapatan rata-rata dari seluruh responden saat ini adalah sebesar $\mathrm{Rp}$ 935.200,00 atau menurun sekitar 30 persen dengan standar deviasi sebesar Rp 1.119.419,00. Imbas dari penurunan pendapatan harian yang diperoleh para pedagang makanan jajanan, maka net income (pendapatan bersih) per hari pedagang pun mengalami penurunan sekitar 30 persen juga.

Meskipun pendapatan harian para pedagang mengalami penurunan drastis sejak wabah Covid-19 menghantam negara Indonesia, namun pendapatan rata-rata para pedagang jauh lebih tinggi dari upah minimum bulanan kota Jakarta. Maka tidak mengherankan sektor informal ini menjadi salah satu primadona bagi banyak orang untuk terjun ke bisnis ini meskipun negara Indonesia masih berada dalam kondisi sulit akibat pandemi Covid-19. Selain itu, besarnya pendapatan yang diperoleh para pedagang memperlihatkan betapa pentingnya peranan sektor informal seperti PKL pada kondisi pandemi seperti sekarang ini. Pekerjaan sebagai PKL makanan jajanan bukan hanya menyelamatkan kehidupan para pedagang dan anggotanya, melainkan juga memberikan kontribusi signifikan terhadap perekonomian negara.

Hasil penelitian juga memperlihatkan bahwa hampir seluruh responden (96 
persen) menyatakan bahwa pendapatan mereka menurun akibat pandemi Covid19. Hanya empat persen responden yang menuturkan bahwa pendapatan bisnis makanan jajanan mereka meningkat selama adanya pandemi Covid-19.

Tabel 8 memperlihatkan bahwa telah terjadi pergeseran rentang pendapatan dari para pedagang makanan jajanan. Sebelum pandemi Covid-19 melanda Indonesia, sebagian besar responden menyatakan bahwa mereka dapat memperoleh pendapatan harian lebih dari satu juta (44 persen) dan tidak ada satu pun responden yang menyatakan pendapatannya dibawah seratus ribu. Namun ketika pandemi Covid-19 melanda negara Indonesia, hampir sebagian besar responden mengutarakan bahwa mereka mengalami penurunan pendapatan. Saat ini hanya tersisa 26 persen responden yang menyatakan bahwa mereka masih memiliki pendapatan harian diatas satu juta. Sebagian besar responden menyatakan bahwa pendapatan mereka sekarang berkisar antara $\mathrm{Rp} 250.001$ sampai Rp 500.000 (24 persen). Sedangkan empat persen responden mengatakan bahwa sekarang mereka hanya mampu membawa pulang uang ke rumah dibawah seratus ribu rupiah. Hasil penelitian ini telah menunjukkan bahwa betapa pandemi Covid-19 telah menghantam bisnis makanan jajanan yang dijalankan oleh banyak orang di seluruh penjuru negeri. Untuk itu, pemerintah lokal atau daerah bersama-sama dengan pemerintah pusat melalui Kementeriaan Koperasi dan UKM harus memikirkan cara untuk menyelamatkan usaha para pelaku sektor informal ini. Jangan biarkan mereka semakin terjerumus dalam ketidakpastiaan akibat belum selesainya pandemi Covid-19. Berbagai langkah telah dan akan dilakukan oleh pemerintah untuk membantu para pelaku usaha ini, antara lain program bantuan langsung kepada para PKL dan warung, program Banpres Produktif Usaha Mikro (BPUM), subsidi bunga KUR dan non KUR. Namun dari itu semua, kolaborasi dan sinergi antara pemerintah dan lembaga lain seperti Asosiasi Pendamping UMKM, Asosiasi Pedagang Kaki Lima (APKL) untuk bersama-sama dan bergotong royong dalam membantu pelaku UMKM yang terdampak Pemberlakuan Pembatasan Kegiatan Masyarakat (PPKM) lebih diperlukan.

Tabel 8. Rentang Pendapatan Per Hari

\begin{tabular}{|c|c|c|}
\hline \multirow[b]{2}{*}{$\begin{array}{l}\text { Rentang Net Income } \\
\text { Per Hari (Rp) }\end{array}$} & \multicolumn{2}{|c|}{ Persentase } \\
\hline & $\begin{array}{c}\text { Sebelum } \\
\text { Covid }\end{array}$ & $\begin{array}{l}\text { Ketika } \\
\text { Covid }\end{array}$ \\
\hline$<100.000$ & 0 & 4 \\
\hline $100.000-250.000$ & 12 & 22 \\
\hline $250.001-500.000$ & 18 & 24 \\
\hline $500.001-750.000$ & 8 & 16 \\
\hline $750.001-1.000 .000$ & 18 & 8 \\
\hline$>1.000 .000$ & 44 & 26 \\
\hline
\end{tabular}

Penurunan pendapatan harian yang terjadi pada pedagang makanan jajanan berimbas pada net income yang diperoleh para pedagang. Hasil penelitian seperti disajikan pada Tabel 9 memperlihatkan penurunan yang sangat signifikan pada net income yang diperoleh para pedagang tersebut. Hasil beberapa penelitian memperlihatkan bahwa keuntungan yang dapat diperoleh dari bisnis makanan adalah berkisar antara 30 sampai 50 persen. Namun sepertinya kondisi ideal tersebut tidak terjadi pada kondisi saat ini.

Tabel 9. Rentang Net Income Per Hari

\begin{tabular}{|c|r|r|}
\hline \multirow{2}{*}{$\begin{array}{c}\text { Rentang Net Income } \\
\text { Per Hari (Rp) }\end{array}$} & \multicolumn{2}{|c|}{ Persentase } \\
\cline { 2 - 3 } & $\begin{array}{c}\text { Sebelum } \\
\text { Covid }\end{array}$ & $\begin{array}{l}\text { Ketika } \\
\text { Covid }\end{array}$ \\
\hline$<100.000$ & 2 & 34 \\
\hline $100.000-250.000$ & 32 & 20 \\
\hline $250.001-500.000$ & 24 & 14 \\
\hline $500.001-750.000$ & 4 & 10 \\
\hline $750.001-1.000 .000$ & 14 & 2 \\
\hline$>1.000 .000$ & 24 & 20 \\
\hline
\end{tabular}

Sumber: Data Primer (2021) 
Hasil penelitian seperti yang terlihat pada Tabel 9 memperlihatkan dengan jelas bahwa hampir seluruh pedagang menyatakan bahwa net income (pendapatan bersih) yang mereka peroleh menurun drastis. Penurunan tersebut disebabkan oleh pendapatan yang juga menurun secara signifikan. Sebelum pandemi Covid-19, hanya ada dua persen responden yang menyatakan bahwa net income mereka dibawah Rp 100.000,00 namun ketika pandemi terjadi peningkatan secara drastis pedagang yang mengatakan penghasilan bersih mereka dibawah seratus ribu (34 persen). Namun menariknya pedagang yang memiliki penghasilan bersih diatas satu juta sebelum dan ketika pandemi Covid-19 berlangsung tidak terlalu berbeda signifikan, yaitu 24 persen sebelum Covid-19 dan 20 persen ketika Covid-19 terjadi. Hal ini mungkin disebabkan mereka yang memiliki penghasilan bersih diatas satu juta tersebut sudah memiliki pelanggan setia dan menempati lokasi secara permanen, sehingga pendapatan yang diperoleh tidak terlalu terpengaruh dengan adanya pandemi Covid-19.

Secara umum, para responden menjelaskan bahwa pendapatan sehari-hari yang diperoleh dari kegiatan usaha digunakan untuk membiayai kehidupan sehari-hari mereka dan keluarga secara langsung (Tabel 10). Pendapatan yang diperoleh dari usaha PKL makanan jajanan memungkinkan mereka untuk membayar sewa rumah, keperluan rumah tangga, biaya sekolah dan membeli peralatan sekolah dan seragam yang memadai bagi para pedagang yang memiliki anak pada usia sekolah. Secara keseluruhan, dapat disimpulkan bahwa pendapatan yang dihasilkan dari kegiatan penjualan makanan jajanan membantu para pedagang untuk meningkatkan kesejahteraan sosial ekonomi mereka.
Tabel 10. Penggunaan Uang

\begin{tabular}{|l|r|r|}
\hline \multirow{2}{*}{ Penggunaan Uang } & \multicolumn{2}{|c|}{ Persentase } \\
\cline { 2 - 3 } & $\begin{array}{c}\text { Sebelum } \\
\text { Covid }\end{array}$ & $\begin{array}{c}\text { Ketika } \\
\text { Covid }\end{array}$ \\
\hline Pengembangan bisnis & 60 & 40 \\
\hline Ditabung & 82 & 48 \\
\hline Membantu keluarga & 94 & 60 \\
\hline Keperluan sendiri & 50 & 46 \\
\hline Membeli barang & 26 & 6 \\
\hline
\end{tabular}

Sumber: Data Primer (2021)

Meskipun penggunaan uang yang diperoleh dari hasil usaha perdagangan makanan jajanan untuk keperluan seharihari membantu keluarga, namun pandemi Covid-19 telah membawa dampak signifikan terhadap perilaku para pedagang makanan jajanan. Data yang disajikan pada Tabel 10 dengan jelas memperlihatkan terjadinya perubahan perilaku dari para pedagang dalam menggunakan uang uang diperoleh tersebut. Sebelum Covid-19 terjadi mayoritas responden mengatakan bahwa mereka menggunakan uang yang diperoleh untuk membantu keuangan keluarga (94 persen), menabung (82 persen), mengembangkan usaha yang sedang dijalankan (60 persen), bahkan setengah dari responden mengatakan bahwa mereka dapat membeli keperluan sendiri dari uang yang yang diperoleh dari bisnis tersebut. Situasi berubah secara drastis ketika pandemi menghantam negara ini. Terjadi perubahan yang sangat signifikan terhadap perilaku para responden dalam menggunakan uang yang diperoleh tersebut. Saat itu, hanya 60 persen responden mengatakan bahwa mereka masih mampu membiayai dan membantu keuangan keluarga (turun 34 persen dari sebelum Covid-19). Untuk keperluan menabung, hanya 48 persen yang mengatakan bahwa mereka masih menyisihkan uang yang diperoleh dari bisnis untuk ditabung. Penurunan tertinggi dari perilaku para pedagang adalah memanfaatkan uang yang diperoleh untuk membeli barang (6 persen). Hasil 
penelitian ini semakin menunjukkan bahwa pandemi Covid-19 telah membawa dampak negatif terhadap sektor informal terutama PKL makanan jajanan di Jakarta. Hampir sebagian besar responden mengeluhkan pandemi ini dan berharap pandemi segera berlalu dan mereka kembali dapat memperoleh penghasilan seperti semula kala.

\section{KESIMPULAN}

Penelitian ini disusun untuk menganalisis bisnis makanan jajanan di Jakarta sebelum dan ketika Covid-19 berlangsung. Sebagai salah satu sektor informal yang paling terdampak pandemi Covid-19, hasil penelitian memperlihatkan bahwa hampir seluruh perempuan PKL makanan jajanan merasakan dampak pandemi Covid-19 terhadap usaha yang sedang dijalankan.

Sebagian besar responden berpendidikan rendah dan sebagian besar kurang memiliki keterampilan khusus ketika memasuki bisnis makanan jajanan. Mayoritas responden sudah menikah dan memiliki anak antara 2 sampai 3 . Mayoritas agama yang dianut oleh responden adalah Islam dengan etnis Jawa sebagai etnis terbanyak dalam sektor informal ini. Jawa Tengah, Jawa Barat dan Jawa Timur adalah daerah penyumbang paling banyak sektor informal ini.

Kehidupan sehari-hari para wanita pedagang kaki lima ditandai dengan kondisi kerja yang sangat buruk, di mana mereka biasanya bekerja dari pagi hingga larut malam. Waktu yang dihabiskan oleh pedagang wanita untuk berbagai aktivitas, termasuk waktu berjualan dan waktu persiapan berkisar antara 8 - 14 jam setiap hari. Para pedagang lebih memilih untuk menggunakan sepeda motor atau mobil dari rumah mereka ke tempat penjual untuk mengangkut barang-barang mereka.

Sebelum Covid-19 terjadi, 10 persen pedagang di Jakarta memiliki karyawan yang membantu usaha mereka. Namun ketika Covid-19 mewabah, hanya 6 persen pedagang yang masih memiliki karyawan berbayar. Saat ini partisipasi anggota keluarga dalam bisnis yang dijalankan oleh pedagang perempuan adalah 66 persen, meningkat dibandingkan sebelum Covid19 yang hanya 62 persen.

Di Jakarta, selama pandemi Covid-19, mayoritas responden (96 persen) mengalami penurunan pendapatan, hanya 4 persen yang menyatakan pendapatannya meningkat. Penelitian menunjukkan bahwa responden mengalami penurunan omzet harian sebesar 30 persen, begitu pula dengan penghasilan bersih yang diperoleh juga menurun sekitar 30 persen. Meskipun demikian, pendapatan harian rata-rata perempuan pedagang kaki lima di Jakarta setidaknya dua lebih tinggi dari upah minimum resmi yang diperoleh pekerja sektor publik. Para responden menyatakan bahwa pendapatan sehari-hari yang diperoleh dari kegiatan usaha digunakan untuk membiayai kehidupan sehari-hari keluarga mereka dan sisanya digunakan untuk menabung dan mengembangkan bisnis.

Berdasarkan hasil penelitian yang sudah dilakukan penulis memberikan beberapa rekomendasi terhadap perkembangan bisnis makanan jajanan yang dijalankan oleh kaum perempuan, yaitu adanya sinergi antara pemerintah daerah DKI Jakarta dengan pemerintah pusat (Kementeriaan Koperasi dan UKM) untuk membantu para pedagang yang sangat terdampak pandemi Covid-19. Selain itu, pemerintah harus tetap memberikan bantuan langsung kepada para pedagang melalui bantuan Produktif Usaha Mikro (BPUM), serta memberikan bantuan kredit dengan subsidi bunga buat pedagang yang masih membuka usahanya.

\section{UCAPAN TERIMA KASIH}

Penulis ingin menyampaikan terima kasih kepada pihak-pihak yang telah berkontribusi dalam penelitian ini terutama para responden perempuan pedagang kaki lima makanan jajanan di Jakarta, Pusat Riset dan Pengabdian Masyarakat (PRPM) Institut Shanti Bhuana serta seluruh pihak 
yang tidak dapat penulis sebutkan satu per satu yang telah membantu penulis dalam penelitian ini.

\section{DAFTAR PUSTAKA}

Adhikari, D.B. (2017). Informal Street Food Trade: A Source of Income Generation in Urban Nepal. Economic Journal of Development, 23 \& 24(1-2), 1-17.

Alves da Silva, S., Cardoso, R. C. V., Góes, J. Â. W., Santos, J. N., Ramos, F. P., Bispo de Jesus, R., \& Teles da Silva, P. S. (2014). Street Food on the Coast of Salvador, Bahia, Brazil: a study from the Socioeconomic and Food Safety Perspectives. Journal of Food Control, 40, 78-84.

Beni, S., Sadewo, Y.D., Manggu, B. (2021). Kesejahteraan Masyarakat dan Pertumbuhan Ekonomi di Perbatasan Jagoi Babang Kalimantan Barat Melalui Pemberdayaan. Inovasi Pembangunan: Jurnal Kelitbangan, 9(2), 125-140.

Bhat W. K. (2000). Profile of Street Foods Sold in Asian countries. World Review of Nutrition and Dietetics, 86, 53-99.

Choudhury, M., Mahanta, L., Goswami, J., Mazumder, M., \& Pegoo, B. (2011). Socio-economic Profile and Food Safety Knowledge and Practice of Street Food Vendors in the City of Guwahati, Assam, India. Journal of Food Control, 22, 196-203.

Chung, C., Ritoper, S., \& Takemoto, S. (2010). Case Study: Bangkok and Access to Food for Low-Income Residents. Department Urban and Planning, Massachusetts Institute of Technology, Massachusetts.

Darko-Koomson, S. (2016). Dynamics and Growth of Street Food Enterprises in Kumasi Metropolis. (Unpublished master thesis). Department of Agricultural Economics, Agribusiness and Extension in the Faculty of Agriculture, College of
Agriculture and Natural Resources, Kumasi.

Etzold, B., Hossain, Md., \& Rahman, S. (2013). Street Food Vending in Dhaka: Livelihoods of the Urban Poor and the Encroachment of Public Space. Bangladesh Institute of Planners, Dhaka.

FAO. (2012.) Social Protection for Food Security. A Report by The HighLevel Panel of Experts on Food Security and Nutrition: June 2012. HLPE Report 4. FAO, Rome.

Fixy, F. (2004). The Contribution of the Informal Sector to Development: A Study of Street Food Vendors in Jakarta Indonesia. (Unpublished master thesis). Massey University, Wellington.

Gadaga, T.H., Ntsike, M.M., \& Ntuli, V. (2014). Socio-economic and Hygienic Aspects of Street Food Vending in Maseru City, Lesotho. USWA Research Journal of Agriculture, Science and Technology, 15, 28-39.

Gengaiah, U., Li, J., Hanvatananukul, H., Prontadavit, N., \& Pilz, M. (2018). Skill Development in the Informal Sector in China, Thailand and India A Case Study of Street Food Vendors. Journal of TVET@ Asia, 10, $1-21$.

Habib, K.R. (2016). Understanding Challenges Faced by Street Food Vendors to Maintain Street Food Hygiene in Dhaka City. Journal of Food and Nutrition Sciences, 4(4), 78-85.

Hariyani, T. (2021). Strategi Pedagang Kaki Lima Dalam Mempertahankan Usaha di Tengah Pandemi Covid-19. Jurnal Ekuivalensi, (7)1, 147-164.

ILO. (2016). Women at Work: Trends 2016. ILO, Geneva.

Irianto, A. M. (2014). Strategi Adaptasi PKL Kota Semarang: Kajian Tentang Tindakan Sosial. International 
Journal of Indonesian Society and Culture, 6(1), 70-90.

Jores, D., Taha, Mohamad, A., \& Rahman, M.D. (2018). Factors Associated with Food Hygiene Practices Among Street Food Vendors in Padawan, Sarawak. Borneo Journal of Resource Science and Technology (2018), 8(1), 56-65.

Kumar, P. (2015). Socio - Economic Features of Street Vending Enterprises in Kerala. International Journal of Management and Commerce Innovations, 3(1), 750756.

Kumar, S., \& Pillai, N. (2017). Problems of Street Vendors in Kollam District. International Journal of Informative \& Futuristic Research (IJIFR), 4(9), 77-91.

Kantachote, K. (2013). Educational Stratification in Thailand: Gender and Residency Effects. (Unpublished master thesis). Lehigh University, Pennsylvania.

Kusakabe, K. (2006). Policy Issues on Street Vending: An Overview of Studies in Thailand, Cambodia and Mongolia. International Labour Organization, Rome.

Lin, E.Y., \& Yamao. M. (2014). Street Foods Safety in Yangon: A Case Study on Street Food Vendors' Socio-Economic and Production Aspects. International Review of Research in Emerging Markets and the Global Economy Journal, 5(1), 206-216.

Lund, F. (2009). Social Protection and the Informal Economy: Linkages and Good Practices for Poverty Reduction and Empowerment. WIEGO Social Protection Programme, University of KwaZuluNatal, Durban.

Maneepong, J., \& Walsh, C. (2013). A New Generation of Bangkok Street vendors: Economic Crisis as Opportunity and Threat. Journal of Cities, 34, 37-43.
Marras, S. (2018). Street Food in Tanzania: A literature Review. FAO, Rome.

Nirathron, M. (2006). Fighting Poverty from the Street: A Survey of Street Food Vendors in Bangkok. International Labour Office, Bangkok.

Njaya, T. (2014). Nature, Operations and Socio-Economic Features of Street

Sinaga, R., \& Purba, M.R. (2021). Pengaruh Virus Corona (Covid-19) Terhadap Pendapatan Pedagang Sayur dan Buah di Pasar Tradisional "Pajak Pagi Pasar V" Padang Bulan. Jurnal Regionomic, 2(2), 37-48.

Sugiyono. (2011). Metodologi Penelitian Pendidikan. Bandung: Alfabeta.

Thanh, T.N. (2015). Food Safety Behavior, Attitudes and Practices of Street Food Vendors and Consumers in Vietnam. (Unpublished master thesis), Ghent University, Gent.

Tinker, I. (2003). Street Foods: Traditional Microenterprise in a Modernizing World. International Journal of Politics, Culture and Society, 16(3), 331-349.

WFP. (2017). Empowering Women in West African Markets Case Study of Street Food Vendors in Maiduguri, Nigeria. World Food Programme Bureau Regional, Dakar.

Yusuf, D., Trossbach, W., \& FreytagLeyer, B. (2020). Women Migrant Street Food Vendors in Tangerang (Indonesia) and Hat Yai (Thailand): Family, Labour, and Income. Kassel: UniKassel Press.

Yusuf, D., \& Freytag-Leyer, B. (2020). Causes and effects of women ruralurban migration - Field study amongst female street food vendors in Tangerang, Indonesia and Hat Yai, Thailand. Proceedings of the 2020 International Conference "Economic Science for Rural Development" No 54 Jelgava, LLU ESAF, 12-15 May 2020, pp. 13-20 
Yusuf, D., \& Freytag-Leyer, B. (2019a). Assessment of the socio-economic aspects and hygiene practices of women street food vendors: Evidence from Indonesia and Thailand. In: 6th International Conference on Food Security and Nutrition (ICFSN 2019), Barcelona, Spain.

Yusuf, D., \& Freytag-Leyer, B. (2019b). Street Foods can be a source of livelihood for women in Tangerang, Indonesia and Hat Yai, Thailand. In: Asian Congress of Nutrition 2019, Bali, Indonesia.

Yusuf, D., Freytag-Leyer, B., \& Trossbach, W. (2013). Street food and its effects on society and customer satisfaction in Malang East Java, Indonesia. (Unpublished Master Thesis). Kassel University, Kassel.

Maria C, (2017). Analisis Sektor Potensial dan Transformasi Struktural di Provinsi Kalimantan Tengah Tahun 2010 - 2016. Jurnal Inovasi Pembangunan Volume 05 No. 3.

Muhtarom, S. (2018). Bangunan Analisis Indeks Desa Untuk Mengetahui Perkembangan Desa Di Kecamatan Gadingrejo Kabupaten Pringsewu. Jurnal Inovasi Pembangunan Volume 06 No. 2. 
Halaman Kosong 